研 究

\title{
$\mathrm{Mg}_{2} \mathrm{Si}$ の固相合成に及ぼす粉体特性および圧粉条件の影響
}

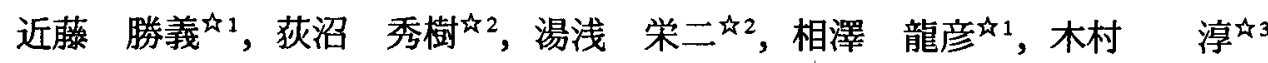 \\ 41 東京大学先端科学技術研究センター, 干 1534-8904 目黒区駒場 4-6-1. \\ 中2 武蔵工業大学工学部機械工学科, 干 158-8557 世田谷区玉堤 1-28-1. \\ 的3住友電気工業秼特性評価センター, 干 554-0024 大阪市此花区島屋 1-1-3.
}

\section{Influences of Powder Characteristic and Compacting Condition on Solid-State Synthesis of $\mathrm{Mg}_{2} \mathrm{Si}$}

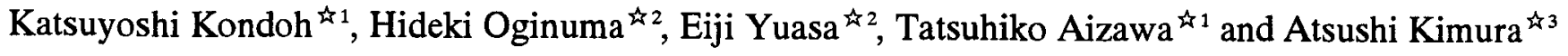 \\ ${ }^{41}$ RCAST, University of Tokyo, 4-6-1 Komaba, Meguro-ku, Tokyo 153-8904.

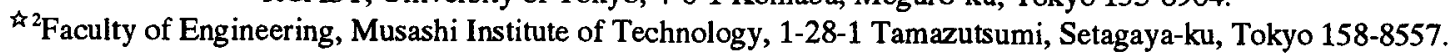 \\ ${ }^{4}{ }^{3}$ Analytical Characterization Center, Sumitomo Electric Industries Ltd., 1-1-3 Shimaya, Konohana-ku, Osaka 554-0024.
}

Received May 14, 2001

\section{SYNOPSIS}

The influence of the raw powder characteristics and compacting condition on the solid-state synthesis of $\mathrm{Mg}_{2} \mathrm{Si}$ from elemental $\mathrm{Mg}-\mathrm{Si}$ mixture powder has been examined by thermal analysis using DSC thermogram. The $\mathrm{Mg}_{2} \mathrm{Si}$ synthesis progresses at the lower temperature range when employing the fine $\mathrm{Mg}$ powder, because of the increase in the contacting area between the $\mathrm{Mg}$ and $\mathrm{Si}$ particles. In employing fine Si powder, the endothermic heat due to the appearance of liquid phase of $\mathrm{Mg}$ at $920 \mathrm{~K}$ decreases remarkably. $\mathrm{MgO}$ film, covering the $\mathrm{Mg}$ powder surface, prevents the $\mathrm{Mg}_{2} \mathrm{Si}$ synthesis due to its thermal stability, however $\mathrm{SiO}_{2}$ surface film is not so effective because of the deoxidization by $\mathrm{Mg}$ during heating. Concerning the effect of the compaction pressure, when the hard Si particles are embedded in the $\mathrm{Mg}$ powder after compacting the mixture powder, the mechanical breakage of the thermally stable $\mathrm{MgO}$ surface film occurs. Therefore, the enlargement of the contacting clean area between $\mathrm{Mg}$ and $\mathrm{Si}$ particles causes the progress of the $\mathrm{Mg}_{2} \mathrm{Si}$ synthesis at the lower temperature.

\section{KEYWORDS}

solid-state synthesis, $\mathrm{Mg}_{2} \mathrm{Si}$, differential scanning calorimeter, surface oxide film, contacting area, compacting pressure

\section{1 緒 言}

マグネシウムシリサイド $\left(\mathrm{Mg}_{2} \mathrm{Si}\right)$ は $700 \mathrm{~K}$ 付近までの中間温 度域で稼動する $\mathrm{n}$ 型半導体用熱電変換材料といった機能性材 料としての特徴を有する一方,これとは別に高硬度・耐熱性・ 低熱膨張率を活かした構造用材料といった異なる分野への適 用が考えられる.特に熱電変換材料においては, $\mathrm{Mg}_{2} \mathrm{Si}$ の他に $\mathrm{FeSi}_{2}, \mathrm{MnSi}_{1.7}, \mathrm{Si}_{0.7} \mathrm{Ge}_{0.3}$ などに関する研究 $\left.{ }^{1,2}\right)$ が行なわれている が, 移動体への搭載を考えた際には軽量化は重要な課題の一 つであり， $\mathrm{Mg}_{2} \mathrm{Si}$ の比重は上記の化合物に比べて約 50〜60\% であることから近年, 注目され始めている ${ }^{3.4}$. なお, $\mathrm{Mg}_{2} \mathrm{Si}$ は $\mathrm{CaF}_{2}$ 型金属間化合物であり，Si が属するIVB族の他元素 $(\mathrm{Ge}$, $\mathrm{Sn}, \mathrm{Pb})$ も同様に $\mathrm{Mg}_{2} \mathrm{X}$ 型の金属間化合物を形成するが，これ までにこれら化合物の特性や合成プロセスに関する研究成果 について詳しく報告されておらず，特に導体・半導体の特性 発現を含めて熱電変換材料としての性能評価の観点からも興
味深い材料でもある.ところで, $\mathrm{Mg}_{2} \mathrm{Si}$ のバルク化に関して は, 従来から主としてメカニカルアロイング(MA)法を利用し て Mg と Si の混合素粉末から固相状態て $\mathrm{Mg}_{2} \mathrm{Si}$ 粉体を合成 ${ }^{5.0}$ し, 放電プラスマ焼結法(SPS)などを使って焼結・固化するプ ロセスが検討されているの.このような方法では，長時間の MA過程での媒体からの Fe や Crあるいは $\mathrm{ZrO}_{2}$ 等の不純物の 混入やSPSによる 3 次元複雑形状固化に対する制約，さらに は MA 後の微細粉末の取り扱いなどの課題があることから， $\mathrm{Mg}_{2} \mathrm{Si}$ の実用化に際しては克服すべき課題が末だ多く残ってい るのが現状である。

そこで, 本研究では MA法も含めた一般的な粉末治金プロ セスにおける $\mathrm{Mg}_{2} \mathrm{Si}$ の合成挙動に及ぼす原料粉末および圧粉. 焼結条件の影暗を解析することで，微細構造を有する $\mathrm{Mg}_{2} \mathrm{Si}$ 合成のための低温固相プロセスを確立すると共に，本合成プ ロセスにより構造用材料としてのマグネシウム基複合材料の 
創製および評価を行なうことを目的とする．先ず，本報では $\mathrm{Mg}-\mathrm{Si}$ 混合素粉末を用いて反応合成法により $\mathrm{Mg}_{2} \mathrm{Si}$ を創製す る際の生成機構に及ぼす原料粉末および圧粉成形条件の影響 を明らかにする。

\section{2 実験方法}

$\mathrm{Mg}$ 粉末およびSi粉末を出発原料とした場合における $\mathrm{Mg}_{2} \mathrm{Si}$ の固相反応合成を考えると, 両粉末における新生面, つまり 粒子表面の酸化皮膜が除去された領域での接触状態が反応挙 動を支配することは容易に推察できる．ゆえに，粒子径，比 表面積あるいは酸素含有量などの粉体特性や圧粉時の加圧力
などの影響を明らかにする必要がある. 本実験では, Table 1 に示すような異なる平均粒子径をもつ $\mathrm{Mg}$ 粉末(いずれも純度 99.9\%) および Si 粉末 (同 99.99\%) を準備した. Fig.1 に走査型 電子顕微鏡 $(\mathrm{SEM})$ による $\mathrm{Mg}$ 粉末および $\mathrm{Si}$ 粉末の概観写真を 示す. 粒度分布に関しては, $\mathrm{Mg}$ 粉末 [III] を除いて全てレー ザー回折散乱法により,また Mg [III]は笠い分けによってそれ ぞれ測定した.試料粉末中の酸素含有量の測定には高周波燃焼 による赤外線吸収法を用いた.これらの粉末を $\mathrm{Mg}-33.33 \mathrm{~mol} \% \mathrm{Si}$ の組成に配合し, 乳鉢を用いて混合した後, 各混合粉末 $0.5 \mathrm{~g}$ を直径 $8 \mathrm{~mm}$ の超硬製金型に充填し，常温にて面圧 100,300 , $600 \mathrm{MPa}$ の3条件下で圧粉成形した. 得られた圧粉体の密度は

Table 1 Characteristics of raw powder employed in this study.

\begin{tabular}{lcccccc}
\hline & \multicolumn{3}{c}{ Mg powder } & \multicolumn{3}{c}{ Si powder } \\
& [ I ] & {$[$ II] } & {$[$ III] } & {$[\mathrm{S}]$} & {$[\mathrm{M}]$} & {$[\mathrm{L}]$} \\
\hline Mean particle size, $D_{0}(\mu \mathrm{m})$ & 57.8 & 105.1 & 1425 & 19.1 & 34.1 & 105.2 \\
Oxygen content (mass\%) & 0.21 & 0.15 & 0.01 & 0.67 & 0.19 & 0.09 \\
\hline
\end{tabular}
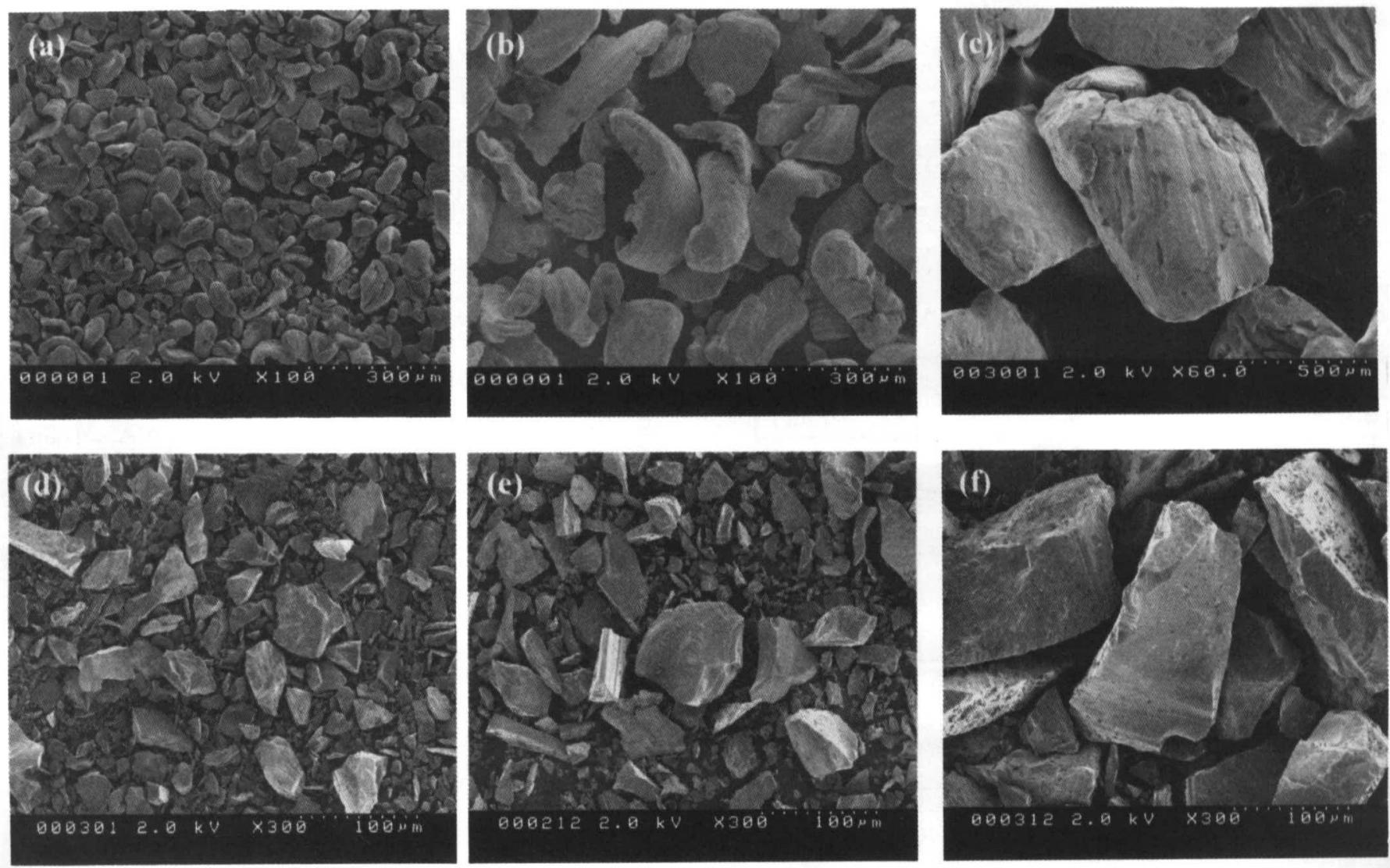

Fig.1 SEM observation on the raw powder, (a) $\mathrm{Mg}[\mathrm{I}]$, (b) $\mathrm{Mg}$ [II], (c) $\mathrm{Mg}[\mathrm{III}]$, (d) $\mathrm{Si}[\mathrm{S}]$, (e) $\mathrm{Si}[\mathrm{M}]$ and (f) $\mathrm{Si}[\mathrm{L}]$ powders. 
アルキメテス法によって測定した. 各圧粉体試料は小片に粉砕 した後, アルゴンガス雾囲気中で示差熱量分析(DSC) を行なっ た. 測定時の昇温速度は $0.33 \mathrm{~K} / \mathrm{s}$ 一定とし, 試料重量は $5.0 \mathrm{mg}$ とした. なお, 圧粉する前の混合粉末についても同様の方法 でDSC分析を行なった.さらにDSC分析結果に基づき, 混合 粉末を $623 \mathrm{~K} \sim 1003 \mathrm{~K}$ の温度範囲において真空中で 3.6ks の熱 処理を施した後, $\mathrm{Mg}_{2} \mathrm{Si}$ の生成を確認すへく $\mathrm{X}$ 線回折 (XRD) による組織構造変化についても調查した.

\section{3 実験結果}

各混合粉末におけるDSC 分析結果を Fig.2に，また各 DSC 曲線における発熱反応開始温度 $\left(T_{s}\right)$ および最高発熱時のピー ク温度 $\left(\mathrm{T}_{\mathrm{p}}\right)$ を整理した結果を Fig.3に示す. $\mathrm{Mg}$ 粉末の平均粒 子径の減少 (III $\rightarrow \mathrm{I}$ )に伴い，750K〜890K 付近での発熱反応は 低温側に移行しておりこの傾向はSi 粉末の粒子径に依存し ないことがわかる. 特に粗粒の $\mathrm{Mg}$ [III] 粉末では, いずれの
DSC曲線においても発熱反応に続いて $920 \mathrm{~K}$ 付近で吸熱挙動 が見られ，再度発熱反応が確認されるが，このような吸熱反 応は $\mathrm{Mg}$ の液相出現によるものである.また $920 \mathrm{~K}$ 以上では吸 熱反応と発熱反応が同時に進行していることから, $\mathrm{Mg}$ の液相 が生成すると同時に周囲に存在する $\mathrm{Si}$ 粉末と反応して $\mathrm{Mg}_{2} \mathrm{Si}$ を生成すると考えられる. 一方, $\mathrm{Si}$ 粉末の粒子径の違いによ る影響に関して, Fig.3に見るように発熱反応開始温度および 発熱ピーク温度の変化は小さく, $\mathrm{Mg}$ 粉末粒径に比べると $\mathrm{Mg}$ -Si間での合成反応の時間的変化に及ぼす影響は小さいといえ

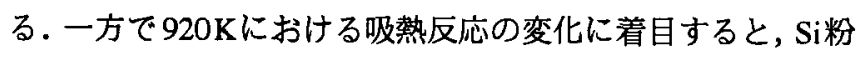
末粒径の減少と共に吸熱量は低下していることから $\mathrm{Mg}$ の液 相出現挙動への影響は $\mathrm{Mg}$ 粉末粒径に比へて明らかに大きい といえる.

$\mathrm{Mg}$ 粉末 [I] を用いた場合の DSC 分析後の試料粉末におけ るX線回折結果を Fig.4に示す.いずれの混合粉末においても $\mathrm{Mg}_{2} \mathrm{Si}$ の回折線のみが検出されており，出発原料で見られる
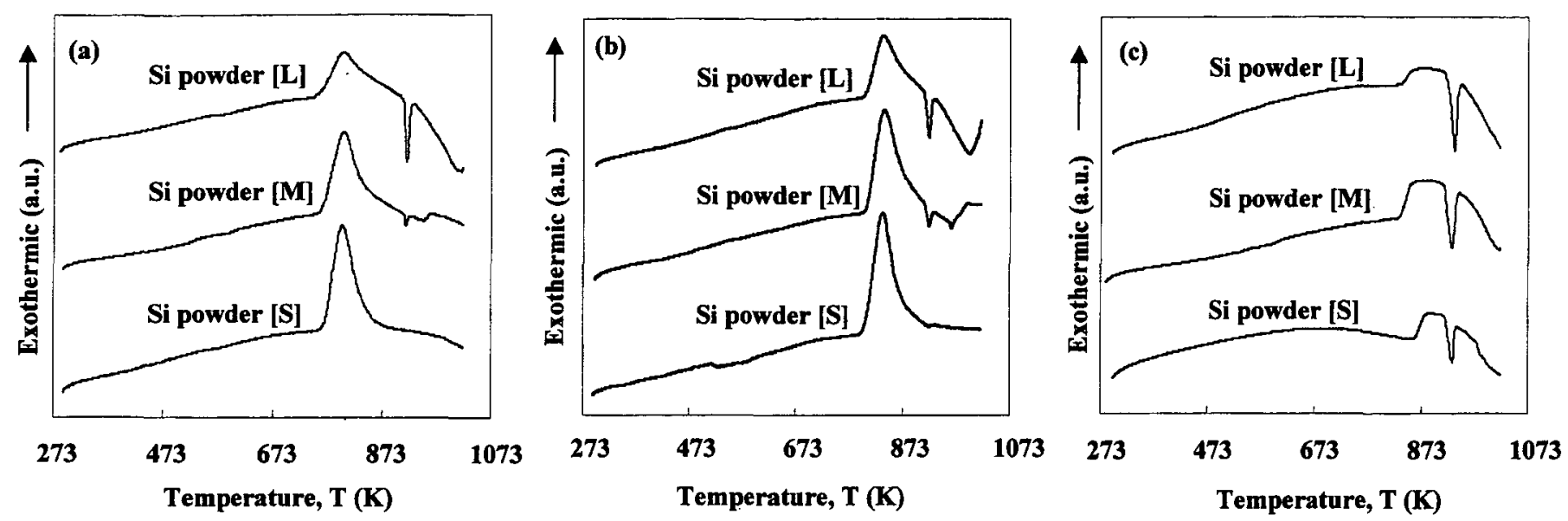

Fig.2 DSC analysis result in employing $\mathrm{Mg}$-Si mixture powder, (a) $\mathrm{Mg}$ [I], (b) $\mathrm{Mg}$ [II], (c) $\mathrm{Mg}$ [III] powder.
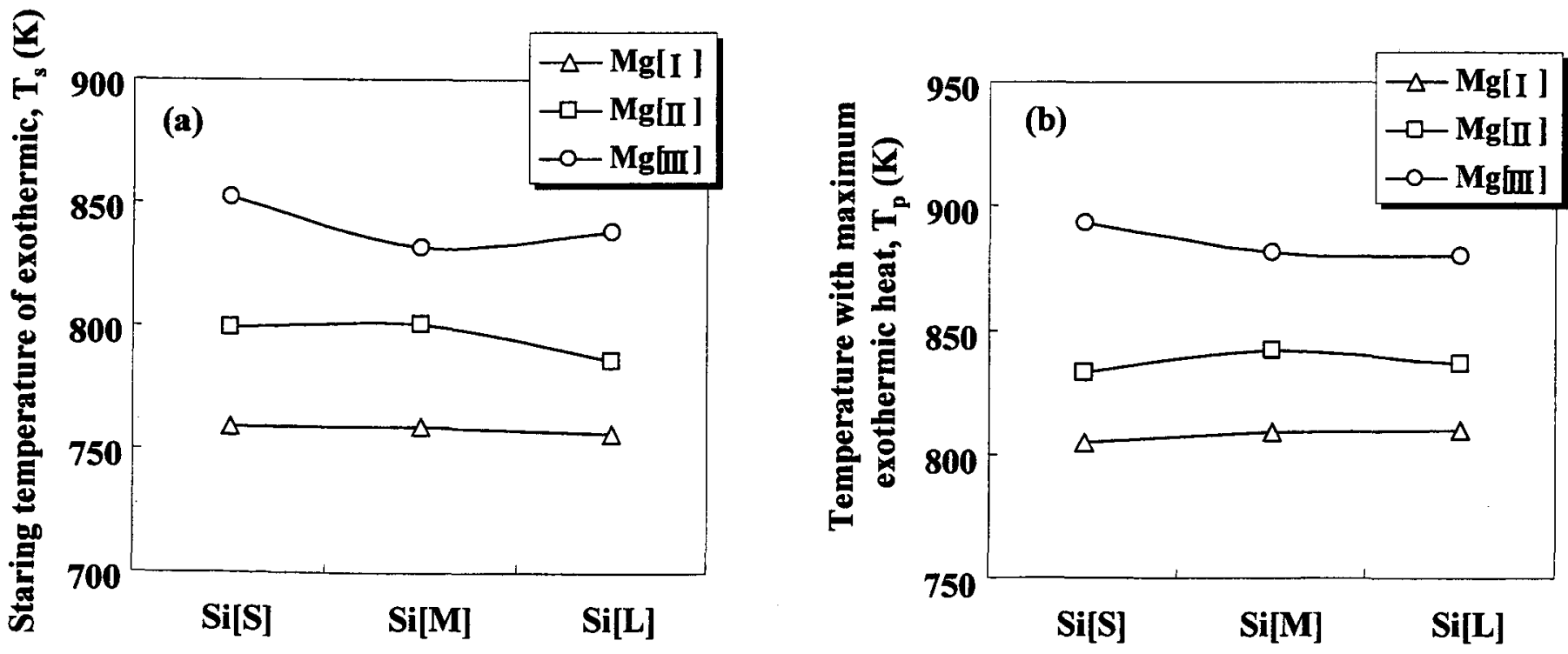

Fig.3 Influence of $\mathrm{Mg}$ and Si raw powders on (a) starting temperature of exothermic and (b) temperature with maximum exothermic heat. 


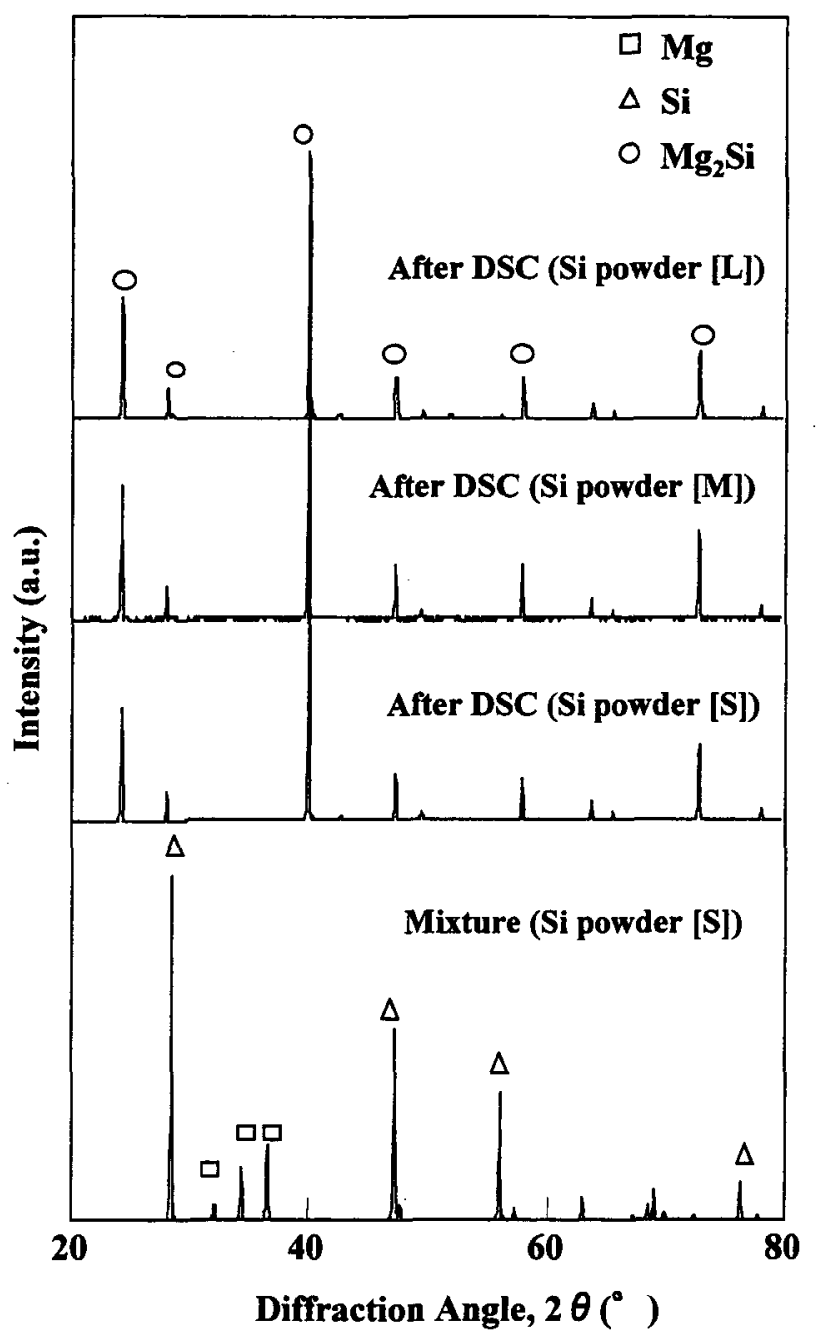

Fig.4 XRD patterns of $\mathrm{Mg}$-Si mixture before and after heating to $1090 \mathrm{~K}$ in DSC analysis.

$\mathrm{Mg}$ および $\mathrm{Si}$ の回折ピークは検出されないことから $1003 \mathrm{~K} ま$ での加熱過程において $\mathrm{Mg}_{2} \mathrm{Si}$ の合成は完了している.そこで, それそれのDSC曲線において観察された発熱反応前後での $\mathrm{Mg}_{2} \mathrm{Si}$ の合成挙動を確認すべく，ここでは $\mathrm{Mg}$ 粉末 $[\mathrm{I}]$ と $\mathrm{Si}$ 粉 末 [S] との混合粉末を Arガス雾囲気中で 623K および $1003 \mathrm{~K}$ にて 3.6ks の熱処理を施し，X線回折を行なった．その結果， Fig.5に示すように $800 \mathrm{~K}$ 付近から始まる発熱ピーク前での回 折パターンにおいては $\mathrm{Mg}_{2} \mathrm{Si}$ のピークは検出されず, 発熱過 程において初めて $\mathrm{Mg}_{2} \mathrm{Si}$ の回折線が検出されており，このこ とからも $750 \mathrm{~K} \sim 890 \mathrm{~K}$ での発熱反応は $\mathrm{Mg}_{2} \mathrm{Si}$ の合成によるも のといえる.

次に，圧粉成形体における $\mathrm{Mg}_{2} \mathrm{Si}$ 合成挙動に及ほす成形条 件の影響に関して,ここでは $\mathrm{Mg}$ [II]粉末を用いた場合の結果 を示す．先ず，圧粉体密度の成形圧力依存性を Fig.6に示す. 600MPaを付与することで圧粉成形体の相対密度は約87〜92\% にまで増加する. また $\mathrm{Si}$ 粉末が微細になるに連れて相対密度 は低下するが,これは Mg-Si 混合粉末の圧密化過程において

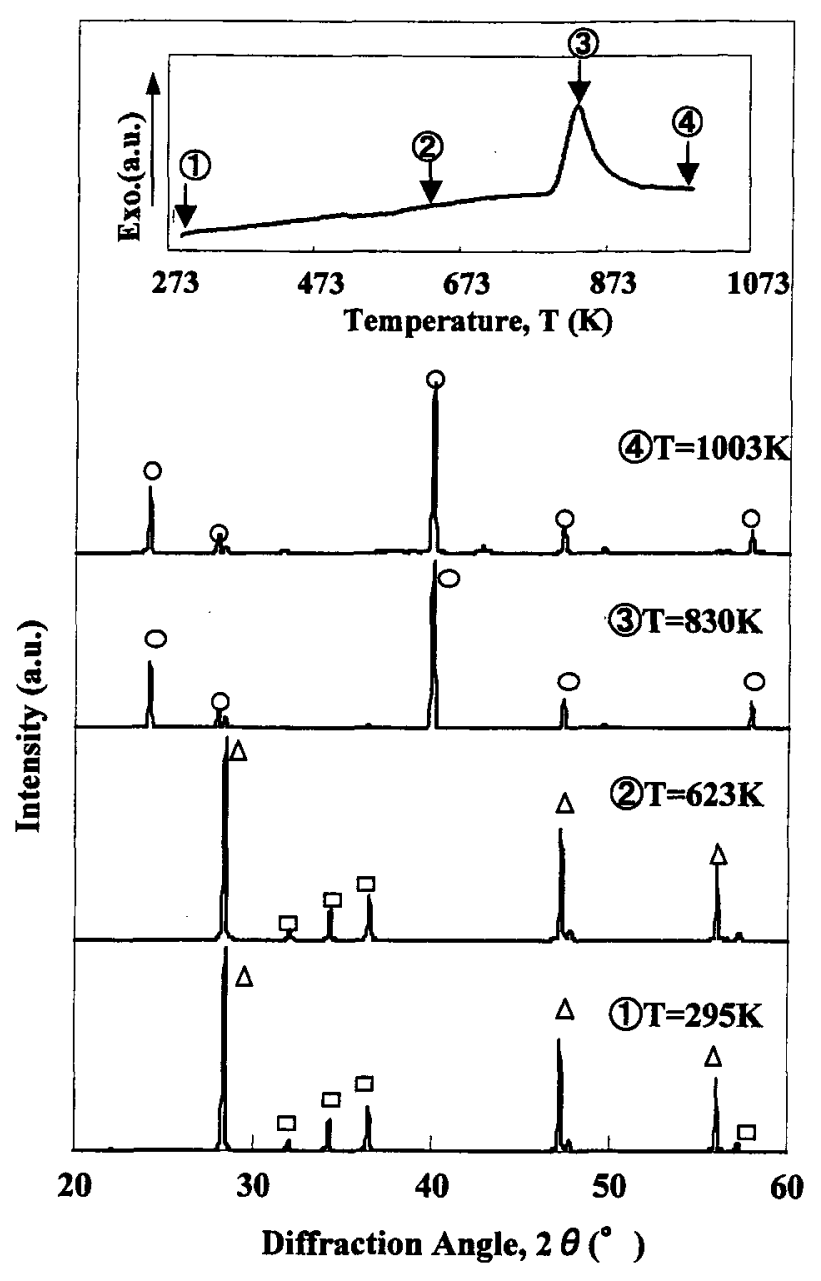

Fig.5 XRD patterns of $\mathrm{Mg}$-Si mixture after heat treatment at various temperatures.

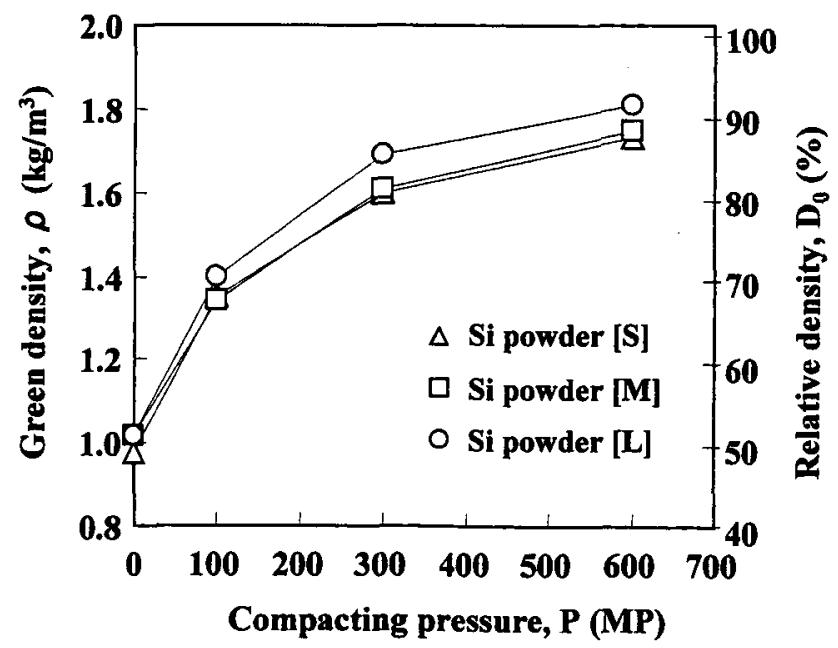

Fig.6 Cold compaction behavior of each $\mathrm{Mg}-\mathrm{Si}$ mixture powder.

Si 粉末の微細化に伴う比表面積の増加によって Mg 粉末表面 ならびに金型壁面とSi粉末粒子間での摩擦が增大し，その結 
果，粒子再配列による圧密化が抑制されたと考えられる．次 に，各圧粉体試料のDSC 分析結果を Fig.7に示す．ここでは 最も微粒な Mg [丁]を用い，Fig.7(a)〜(c) はそれぞれ Si [S]〜Si [L] に対応している.いずれのSi粉末においても発熱挙動に関し ては成形压力の增加に伴って発熱ピークは低温側に移行して ブロードなDSC曲線を呈する傾向にあり, 発熱開始温度に着
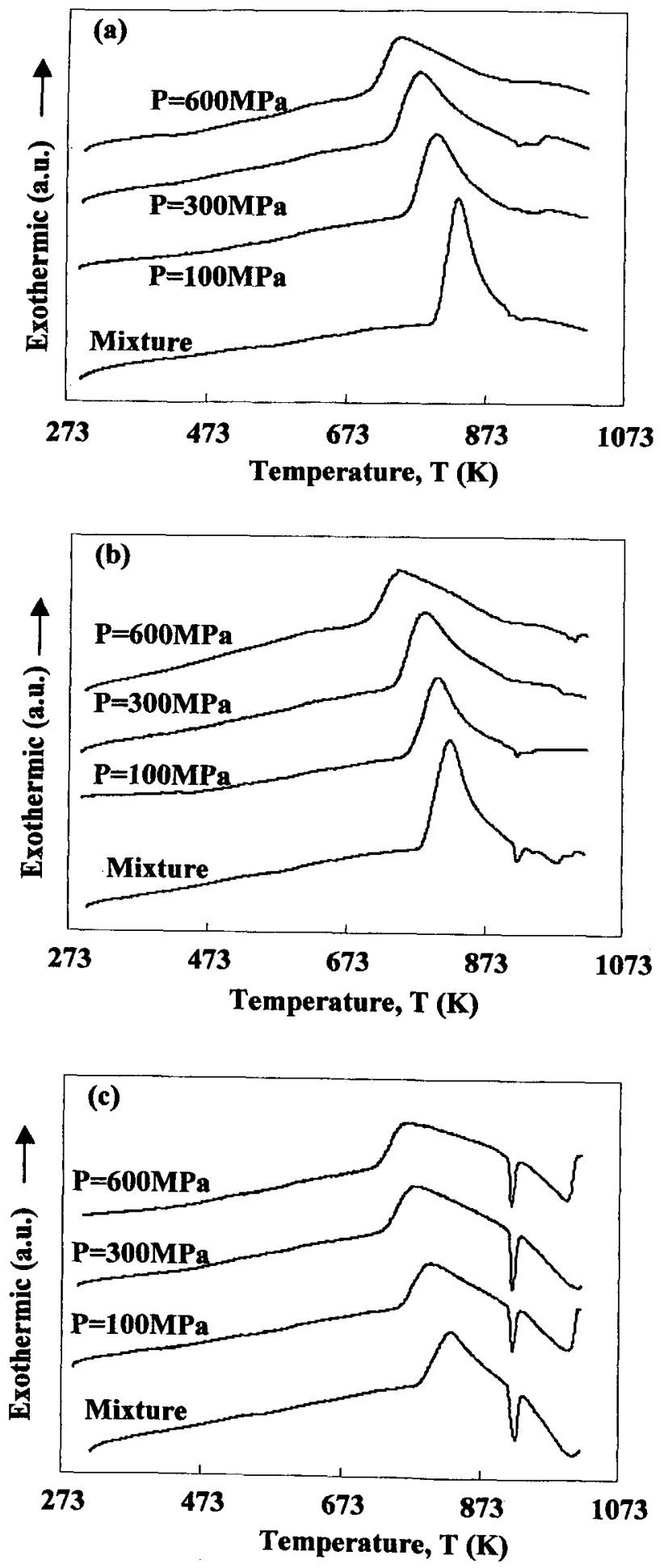

Fig.7 DSC thermograms of green compact consolidated at various pressures, (a) Si [I], (b) Si [II], (c) Si [III] powder.
目すると混合粉末に比べて $100 \mathrm{~K}$ 程度低下している.また $920 \mathrm{~K}$ 付近での $\mathrm{Mg}$ の液相出現による昅熱量は成形圧力の增加と共 に顕著に減少している. Fig.8に Mgの液相が出現する前の発 熱反応における発熱量 $\left(\mathrm{H}_{\mathrm{e}}\right)$ と圧粉体の相対密度の関係を示す. いずれのSi粉末においても圧粉体の相対密度が増加するに連 れて発熱量は増大しており,特に粗粒粉末のSi [L]では顕著な 増加傾向を有するが，これは Fig.7(c)に示した $920 K$ 付近での 吸熱量の減少によるものと考えられる。なお, $\mathrm{Mg}[\mathrm{I}]$ 粉末お よび Mg [III] 粉末のいずれの DSC分析結果においても同様の 傾向が確認されている.

\section{4 考察}

$4.1 \mathrm{Mg}_{2} \mathrm{Si}$ の固相合成に及ほす原料粉末の影響

$\mathrm{Mg}-\mathrm{Si}$ 混合素粉末を用いた固相反応による $\mathrm{Mg}_{2} \mathrm{Si}$ 合成を考 えると，前述したように両粉末間において活性な新生面同土 の接触領域を増加させることが望ましい.そこで先ず，それ それれの原料粉末における酸素含有量および粒子径(接触領域= 比表面積)の影響について考察する，異なる酸素量を有する $\mathrm{Mg}$ 粉末を準備し，これまでと同様にSi $[\mathrm{M}]$ 粉末との混合粉末 についてのDSC分析を行なった結果をFig.9に示す.なお, $\mathrm{Mg}$ 粉末には Mg [II] を用い，これを大気中で温度 $373 \mathrm{~K}$, 加熱時 間 $14.4 \mathrm{ks}$ の酸化処理を施すことによって酸素含有量加增加し た試料を準備した。なお，酸化処理後の酸素量は $0.40 \mathrm{mass} \%$ であった。酸化処理を施した $\mathrm{Mg}$ 粉末を用いることで DSC曲 線は約 $20 \mathrm{~K}$ 程度, 高温側に移動しており，予想される通り $\mathrm{Mg}$ 粉末表面の酸化皮膜の増加によって $\mathrm{Mg}_{2} \mathrm{Si}$ の固相合成が抑制 されたと考えられる.但し，これまでのDSC分析結果で明ら かなように 750 800K 付近で $\mathrm{Mg}_{2} \mathrm{Si}$ の合成反㐫が生じている ことから粉末表面には $\mathrm{MgO}$ 皮膜に覆われない $\mathrm{Mg}$ 新生面か既 に存在していると考えられる.しかしながら,一般に $\mathrm{Mg}$ 粉末 の表面は $\mathrm{MgO}$ を主とする酸化物に覆われ， $800 \mathrm{~K}$ 付近の温度 域でこのような酸化物の熱分解は考え難いことから，乳鉢内

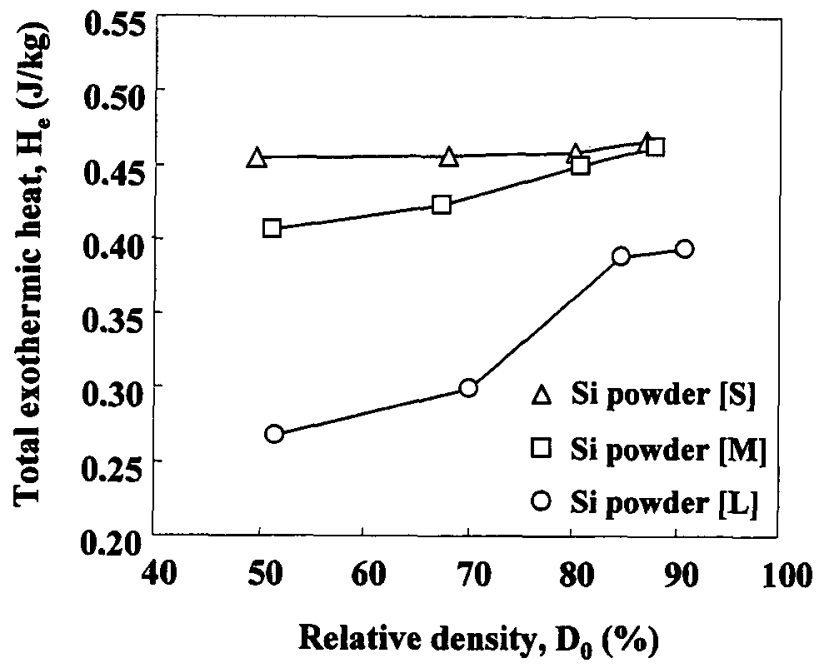

Fig.8 Dependence of total exothermic heat in DSC analysis of $\mathrm{Mg}-\mathrm{Si}$ green compact on relative density. 
においてSi粉末と混合する過程での表面酸化膜の機械的破損， あるいは加热過程における素地 $(\mathrm{Mg})$ と表面酸化皮膜 $(\mathrm{MgO})$ と の熱膨張率 $\alpha$ の差 ${ }^{7,8)}\left(\Delta \alpha=\alpha \mathrm{Mg}-\alpha \mathrm{MgO} \doteqdot 12.5 \times 10^{-6} \mathrm{~K}^{-1}\right)$ に起 因する体積膨張時の酸化皮膜の機械的破壊などが考えられる が,これらについては今後さらなる調査が必要である.一方， Si粉末中の酸素含有量の影響を検討するためにSi $[\mathrm{S}]$ 粉末に近 い粒度分布を有するシリカ $\left(\mathrm{SiO}_{2}\right)$ 粉末(純度 $99.50 \%$ ，平均粒 子径 $21.3 \mu \mathrm{m})$ を準備し，これと $\mathrm{Mg}$ [II]粉末との湦合粉末につ いてDSC分析を行なった. その結果，Fig.10に示すように反 応開始温度および発熱ピーク温度には顕著な差は見受けられ ない。しかしながら， $\mathrm{Si}$ 粉末で見られた吸熱挙動は $\mathrm{SiO}_{2}$ 粉末 では確認されず，また発熱量も $1.1 \mathrm{Jkg}^{-1}$ と $\mathrm{Si}$ 粉末を用いた場 合 $\left(0.46 \mathrm{Jkg}^{-1}\right)$ に比へて 2 倍以上に增大している.DSC 分析を 行なったそれそれの混合粉末についてのX線回折結果を

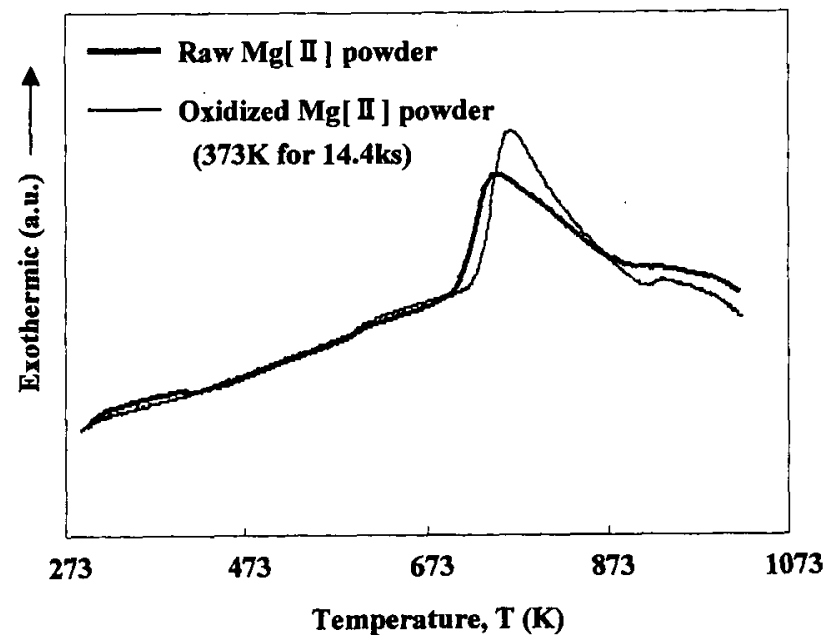

Fig.9 DSC thermogram of $\mathrm{Mg}$-Si mixture in employing $\mathrm{Mg}$ powder before/after oxidization treatment.

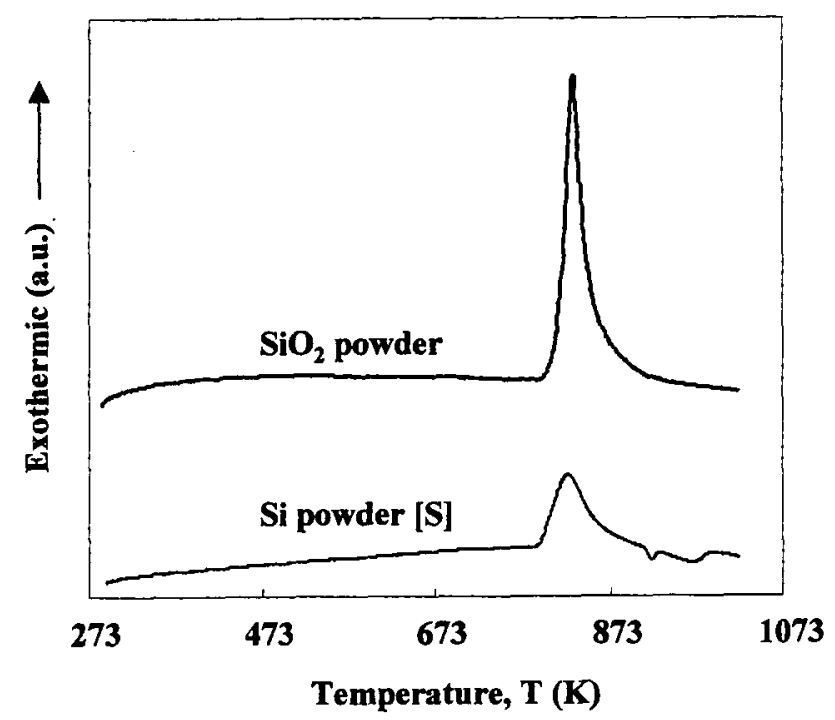

Fig.10 DSC thermogram in employing of $\mathrm{Mg}-\mathrm{SiO}_{2}$ mixture compared to $\mathrm{Mg}$-Si mixture.
Fig.11に示す。(a)に見るように $\mathrm{SiO}_{2}$ 粉末を用いた場合には $\mathrm{Mg}_{2} \mathrm{Si}$ と共に $\mathrm{MgO}$ の回折ピークも検出されており, $\mathrm{Mg}_{2} \mathrm{Si}$ の 合成と共に $\mathrm{MgO}$ も生成する. 以上の DSC分析およびXRDの 結果より, 800K付近からの発熱反応において先ず $\mathrm{SiO}_{2}$ 粉末が $\mathrm{Mg}$ 粉末によって還元され，続いて Si と $\mathrm{Mg}$ の反応による $\mathrm{Mg}_{2} \mathrm{Si}$ の合成と同時に $\mathrm{MgO}$ を形成する酸化反応における発熟 量が加算された結果，引き続き進行する $\mathrm{SiO}_{2}$ 粉末からの $\mathrm{Mg}_{2} \mathrm{Si}$ の合成反応が促進されて $920 \mathrm{~K} て ゙$ 液相となる末反応の $\mathrm{Mg}$ 残存量が減少し，吸热反応が消滅したものと考えられる.

次に, $\mathrm{Mg}$ 粉末および Si 粉末の粒子径の影響に関して, 前 記の Fig.2に示したように Mg粉末においては，平均粒子径の 減少に伴ってDSC曲線における $\mathrm{Mg}_{2} \mathrm{Si}$ 合成時の発熱反応開始 温度が低温側に移動しているが，これは $\mathrm{Mg}$ 粉末の微粒化に 伴う比表面積の增大によって合成反応を支配する $\mathrm{Mg}$ 新生面 の露出面皘が增加したことに加えて，Si粉末との接触領域の 增加も影響していると考えられる。一方，Si粉末については 粒子の微細化に伴って発熱反応開始温度に差はないが，吸熱 反応か減少あるいは消滅している.Mg粉末表面における活性 な $\mathrm{Mg}$ 新生面の形成領域は $\mathrm{Si}$ 粒子径に無関係であるために $\mathrm{Mg}_{2} \mathrm{Si}$ 合成反応開始温度はほとんど変化することはなく,ま た吸熱反応の減少に関しては $\mathrm{Mg}$ の液相が出現するまでの固 相状態の Mg が $\mathrm{Si}$ 粉末と反応して $\mathrm{Mg}_{2} \mathrm{Si}$ を生成し，920Kにお ける $\mathrm{Mg}$ の液相出現量が減少したことを意味する。すなわち， $\mathrm{Si}$ 粉末の比表面積の増加による $\mathrm{Mg}$ 粉末間での接触領域が增 大することで固相状態における $\mathrm{Mg}_{2} \mathrm{Si}$ 合成が促進したものと 考えられる。

以上の結果より，Mg-Si 混合素粉末における $\mathrm{Mg}_{2} \mathrm{Si}$ の固相 合成反応を支配する因子としては，主に $\mathrm{Mg}$ 粉末の表面酸化 膜および粒子径(比表面積)でありSi粉末のそれらに比へてよ り影響度が大きいものと考えられる。

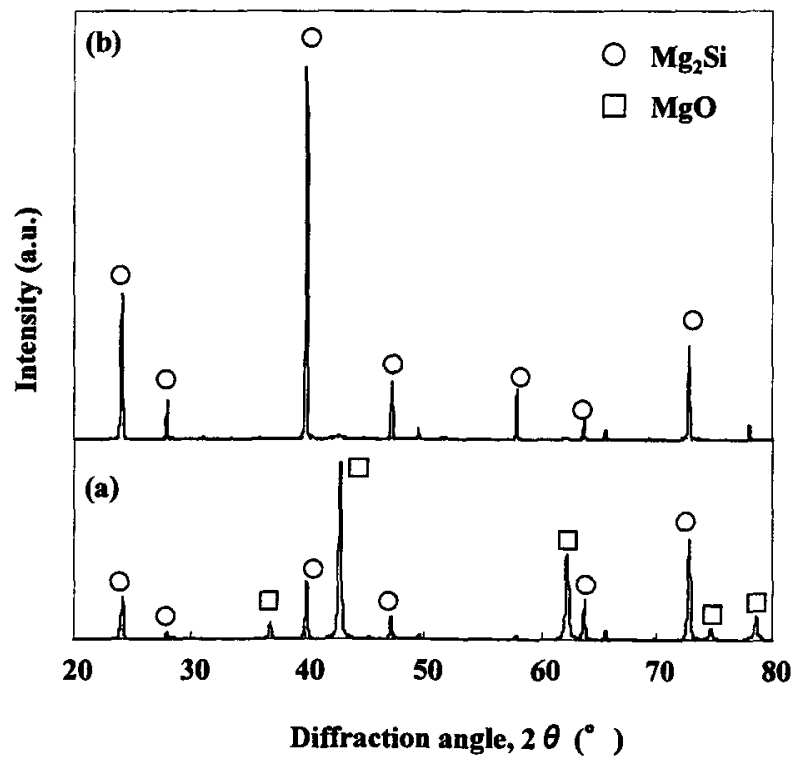

Fig.11 XRD patterns of (a) $\mathrm{Mg}-\mathrm{SiO}_{2}$ mixture and (b) $\mathrm{Mg}-\mathrm{Si}$ mixture after heating to $1090 \mathrm{~K}$ in DSC analysis. 

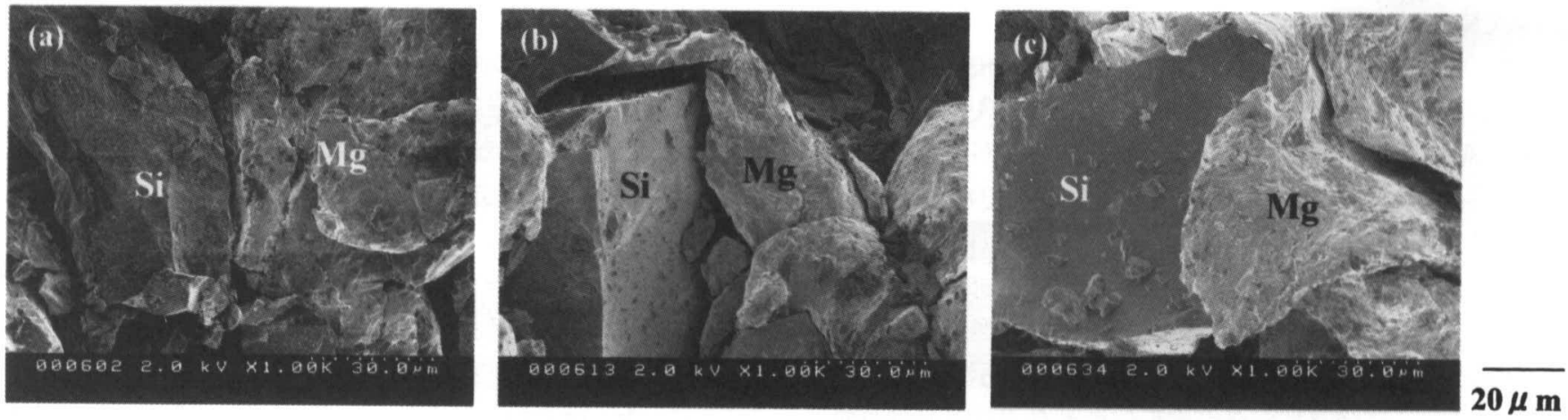

Fig.12 SEM observation on Mg-Si green compact consolidated at (a) $100 \mathrm{MPa}$, (b) $300 \mathrm{MPa}$ and (c) $600 \mathrm{Mpa}$.

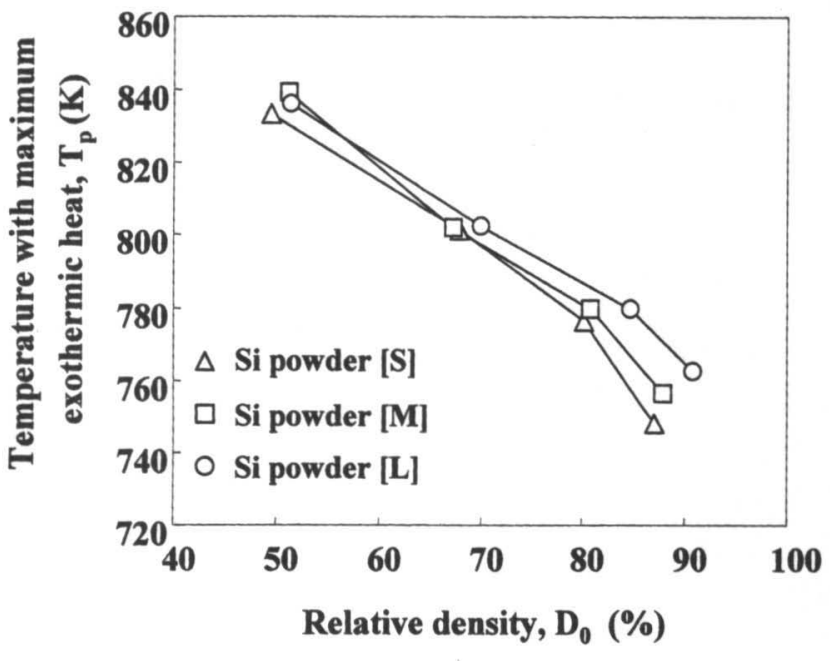

Fig.13 Dependence of temperature with maximum exothermic heat of $\mathrm{Mg}-\mathrm{Si}$ green compact on relative density.

\section{$4.2 \mathrm{Mg}_{2} \mathrm{Si}$ の固相合成に及ぼす圧粉成形圧力の影響}

Fig.7に示したように, いずれの圧粉体においても成形圧力 の増加，すなわち高密度化と共に $\mathrm{Mg}_{2} \mathrm{Si}$ の合成反応はより低 温側に移行する.これはFig.12に示す圧粉体中の Mg粉末と $\mathrm{Si}$ 粉末との接触状態に関する SEM 観察結果からもわかるよう に, 圧粉成形過程で硬質な $\mathrm{Si}$ 粉末が軟質な $\mathrm{Mg}$ 粉末に埋め込 まれ, 高成形圧力側では両粉末はより強固に密着している. つまり, Si 粉末が $\mathrm{Mg}$ 粉末に押し込まれることで $\mathrm{Mg}$ 粉末表面 の酸化皮膜が分解・破断され, その結果, 活性な新生面が形 成されて $\mathrm{Mg}_{2} \mathrm{Si}$ の合成が進み, 併せて圧粉体の相対密度の増 加に伴い, $\mathrm{Mg}$ 新生面での Si 粉末との接触領域が増加するこ とからFig.7のような発熱挙動を示したものと考えられる.特 に Si $[\mathrm{M}]$ および Si [L] においては吸熱反応が成形圧力の増加 に伴って減少しており，これは固相状態の $\mathrm{Mg}$ と $\mathrm{Si}$ との反応

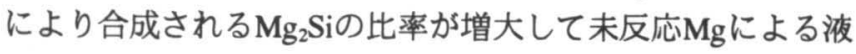
相生成量が減少したことによる.Fig.7に示したDSC曲線の発 熱反応における最高発熱時のピーク温度 $\mathrm{T}_{\mathrm{p}}$ と相対密度 $\mathrm{D}_{0}$ の関 係を Fig.13に示す. ピーク温度は相対密度の増加と共にほほ 直線的に減少しているが, 相対密度が $80 \%$ を超える高密度成

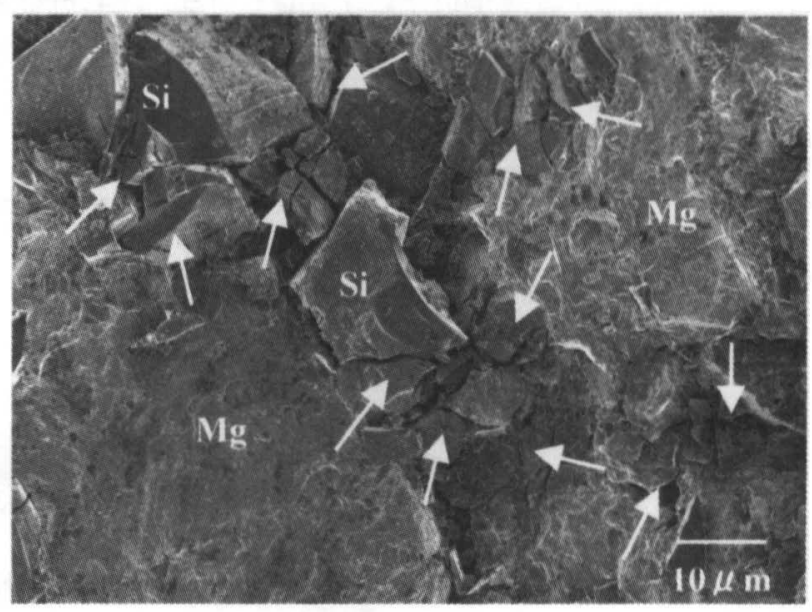

Fig.14 SEM observation on primary particle boundaries of $\mathrm{Mg}-\mathrm{Si}$ green compact consolidated at $600 \mathrm{Mpa}$.

形体ではいずれのSi粉末を用いた場合においても $\mathrm{T}_{\mathrm{e}}$ は直線関 係から外れて僅かながら低下している．このように高密度成 形体において $\mathrm{Mg}_{2} \mathrm{Si}$ の反応合成温度がさらに低温側に移行す ることについては次のように考えられる. 圧粉過程において $\mathrm{Mg}$ および $\mathrm{Si}$ 粉末の粒子再配列機構により粉末間の空隙を閉 鎖することで相対密度が増加するが, 高圧力域では粒子の塑 性変形機構による緻密化が支配的となり, $\mathrm{Mg}$ 粉末間に存在す る Si 粉末は $\mathrm{Mg}$ 粉末に埋め込まれると共に, Fig.14の矢印で 示すように脆性であるため, 特に粗大な粉末は加圧過程で粉 砕されて $\mathrm{Mg}$ 粉末と機械的に接触し, $\mathrm{Mg}$ 粉末表面での酸化皮 膜の破壊・分断に寄与する. その結果, $\mathrm{Mg}$ 新生面と Si 粉末と の接触領域が増加することで発熱反応がより低温側に移行し たと考えられる。

\section{5 結 論}

本研究では, $\mathrm{Mg}-\mathrm{Si}$ 混合素粉末における $\mathrm{Mg}_{2} \mathrm{Si}$ の合成反応 挙動に及ぼす原料粉末および圧粉成形条件の影響について㭘 討した結果, 以下のようなを結論が得られた.

(1) $\mathrm{Mg}$ 粉末の微細化に伴い $\mathrm{Mg}_{2} \mathrm{Si}$ の合成反応は低温側に移行

し, Si 粉末の微細化により $920 \mathrm{~K}$ 付近での Mg の液相出現 
に伴う吸熱反応量は減少する.

(2) 原料粉末の酸素含有量の影響に関して, Mg 粉末表面の $\mathrm{MgO}$ 皮膜の増加は合成を抑制し, 反応は高温側にシフト する.一方の $\mathrm{Si}$ 粉末における $\mathrm{SiO}_{2}$ 量は反応開始温度には 顕著に影響を与えないか， $\mathrm{MgO}$ 生成時の酸化反応に伴う 発熱によって $\mathrm{Mg}_{2} \mathrm{Si}$ の合成反応は促進される。

(3) 圧粉体では $\mathrm{Mg}$ 粉末表面への Si 粉末の埋め込みにより $\mathrm{MgO}$ 表面皮膜が破壊・分断され，その結果，相対密度の 增加に伴って $\mathrm{Mg}_{2} \mathrm{Si}$ の合成温度は混合粉末に比へて約 $100 \mathrm{~K}$ 低温側に移行する。

\section{謝辞}

試料粉末の酸素量分析ならびに粒度分布測定に際して, 多 大な御協力を賜りました日本アトマイス加工株式会社の山本 浩士氏に感謝申し上げます。

文献

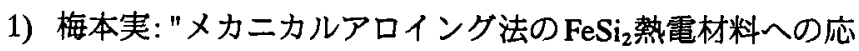

用",粉体および粉末治金, 42(1995)135-140.

2) 永井宏: "メカニカルアロイング法を活用した $\mathrm{FeSi}_{2}$ 系熱電 材料の高性能化",まてりあ, 35 (1996) 952-955.

3) L.Lu, M.O.Lai, W.B.Xue and S.Y.Ng: "Influence of kinetic energy on the formation of $\mathrm{Mg}_{2} \mathrm{Si}$ ", Z. Metallkd., $91(2000) 680-$ 685.

4) 白井善之, 山中裕基, 梅本実, 土谷浩一: " $\mathrm{Mg}_{2} \mathrm{Si}$ の熱電特 性に対する Al 添加の影響", 日本金属学会春期大会講演概 要集, (2001)450.

5) 杉山明, 小林慶三, 尾崎公洋, 西尾敏幸, 松本章宏: " メ力 ニカルアロイングを利用した $\mathrm{Mg}_{2} \mathrm{Si}$ 基複合热電材料の作製", 粉体および粉末治金, 45(1998)952-957.

6)杉山明, 小林慶三, 尾崎公洋, 西尾敏幸, 松本章宏: " メ力 ニカルアロイングーパルス通電焼結プロセスを用いた $\mathrm{Mg}_{2} \mathrm{Si}-\mathrm{FeSi}_{2}$ 傾斜熱電材料の作製", 日本金属学会誌, 11 (1998)1082-1087.

7) Metal reference book, $4^{\text {th }}$ edition, Butterworths, (1967) 46 .

8) Metal reference book, $5^{\text {th }}$ edition, Butterworths, (1970) 37 . 